YEARBOOK

of ANTITRUST

and REGULATORY

STUDIES

www.yars.wz.uw.edu.pl
Peer-reviewed scientific periodical, focusing on legal and economic issues of antitrust and regulation. Creative Commons Attribution-No Derivative Works 3.0 Poland License.

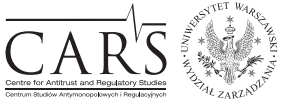

Centre for Antitrust and Regulatory Studies, University of Warsaw, Faculty of Management www.cars.wZ.uw.edu.pl

\title{
Competition Law and State Aid for Failing Banks in the EU and its Specific Implications for CEE Member States
}

\author{
by \\ Virág Blazsek
}

\section{CONTENTS}

I. Introduction

II. EU State Aid Rules and their Interplay with EU Competition Law

III. Changing Interpretation of State Aid Rules and its Impact

IV. CEE Specific Implications of the Changing Interpretation of State Aid Rules

V. Conclusions

\section{Abstract}

The bank bailouts following the global financial crisis of 2008 have been subject to prior approval of the European Commission (EC), the competition authority of the European Union. The EC was reluctant to reject rescue efforts directed at failing banks and so it consistently approved all such requests submitted by Member States. Out of the top twenty European banks, the EC authorized State aid to at least twelve entities. In this context, the paper outlines the gradually changing interpretation of EU State aid rules, the "temporary and extraordinary rules" introduced starting from late 2008, and the extension of the "no-State aid" category. The above shifts show that the EC itself deflected from relevant EU laws in order to systemically rescue important banks in Europe and restore their financial stability.

* Virág Blazsek, Doctoral Candidate, Department of Legal Studies, Central European University, Budapest, Hungary; e-mail: blazsek_virag@phd.ceu.edu or blazsek@gmail.com. Article received: 28 June 2016; accepted: 3 September 2016.

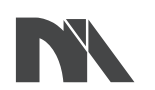

Ministry of Science and Higher Education

Republic of Poland
The creation of the English-language version of these publications is financed in the framework of contract No. 768/P-DUN/2016 by the Ministry of Science and Higher Education committed to activities aimed at the promotion of education. 
The paper argues that bank bailouts and bank rescue packages by the State have led to different effects on market structures and consumer welfare in the Eurozone and non-Eurozone areas, mostly the Eastern segments of the European Union. As such, it is argued that they are inconsistent with the European common market. Although the EC tried to minimize the distortion of competition created as a result of the aforementioned case law primarily through the application of the principle of exceptionality and different compensation measures, these efforts have been at least partially unsuccessful.

Massive State aid packages, the preferential treatment of the largest, or systemically important, banks through EU State aid mechanisms - almost none of which are Central and Eastern European (CEE) - may have led to the distortion of competition on the common market. That is so mainly because of the prioritization of the stability of the financial sector and the Euro. The paper argues that State aid for failing banks may have had important positive effects in the short run, such as the promotion of the stability of the banking system and the Euro. In the longrun however, it has contributed to the unprecedented sovereign indebtedness in Europe, and contributed to an increased economic and political instability of the EU, particularly in its most vulnerable CEE segment.

\section{Résumé}

Les sauvetages bancaires consécutifs à la crise financière mondiale de 2008 ont été soumis à l'approbation préalable de la Commission européenne (CE), l'autorité de la concurrence de l'Union européenne. Les CE étaient réticentes à rejeter les efforts de sauvetage dirigés contre les banques défaillantes et ont donc approuvé de manière cohérente toutes les demandes présentées par les États membres. Sur les vingt premières banques européennes, la CE a autorisé des aides d'État au moins douze entités. Dans ce contexte le document souligne l'évolution progressive de l'interprétation des règles de l'UE en matière d'aides d'État, les «règles temporaires et extraordinaires» introduites à partir de la fin de 2008 et l'extension de la catégorie «sans aides d'État». Les changements susmentionnés montrent que la CE elle-même a dévié des lois pertinentes de l'UE afin de sauver systématiquement d'importantes banques en Europe et de rétablir leur stabilité financière.

Larticle soutient que les plans de sauvetage bancaire et les plans de sauvetage bancaire de l'État ont eu des effets différents sur les structures du marché et sur le bien-être des consommateurs dans les zones de la zone euro et hors zone euro, principalement dans les segments orientaux de l'Union européenne. En tant que tel, il est soutenu qu'ils sont incompatibles avec le marché commun européen. Bien que les CE aient essayé de minimiser les distorsions de concurrence créées par la jurisprudence susmentionnée, principalement par l'application du principe d'exception et des mesures de compensation différentes, ces efforts ont été au moins partiellement infructueux.

Les paquets massifs d'aides d'État, le traitement préférentiel des banques les plus importantes ou systématiquement importantes par le biais des mécanismes d'aide 
de l'UE - presque aucun d'Europe centrale et orientale (CEE) - ont entraîné une distorsion de concurrence sur le marché commun. Cela est dû principalement à la priorité accordée à la stabilité du secteur financier et de l'euro. Le document fait valoir que les aides d'État pour les banques en faillite peuvent avoir eu des effets positifs importants à court terme, comme la promotion de la stabilité du système bancaire et de l'euro. Toutefois, à long terme, elle a contribué à l'endettement souverain sans précédent en Europe et a contribué à accroître l'instabilité économique et politique de l'UE, en particulier dans son segment d'Europe centrale et orientale le plus vulnérable.

Key words: EU Competition Law; Central and Eastern Europe (CEE); financial crisis; State aid; bank bailouts; Eurozone; sovereign debt; European Stability Mechanism (ESM).

JEL: K21

\section{Introduction}

The bank bailout cases following the financial crisis of 2008 were subject to prior approval of the European Commission (hereinafter, EC or Commission), the competition authority of the European Union. The Commission was reluctant to reject the rescue efforts directed at failing banks and consistently approved all related requests submitted by EU Member States. Out of the top twenty European banks, the EC ended up authorizing State aid to at least twelve financial institutions (Adamczyk and Windisch, 2015, p. 1).

State aid - the intervention of the State into the market economy - is a matter of a policy decision and is highly controversial because of its short and long term effects on market competition (Adler, Kavanagh and Ugryumov, 2010, p. 66; Lipinsky and Wolters, 2016, p. 193). It is only one of the at least three methods of providing financial assistance to financially distressed corporations, and it involves taxpayer's money. The two alternatives methods include "private money solutions" (where financial aid is provided by private investors, other financial institutions or banks) and "monetary policy solutions" implemented by central banks, which are basically liquidity assistances either in ordinary or in emergency situations ${ }^{1}$. As compared to the pre-crisis years, the role of central banks as "lenders of last resort" has

\footnotetext{
${ }^{1}$ See Directive 2014/59/EU of the European Parliament and of the Council of 15 May 2014 establishing a framework for the recovery and resolution of credit institutions and investment firms and amending Council Directive 82/891/EEC, and Directives 2001/24/EC, 2002/47/ EC, 2004/25/EC, 2005/56/EC, 2007/36/EC, 2011/35/EU, 2012/30/EU and 2013/36/EU, and
} 
increased as a result of the 2008 financial crisis on both sides of the Atlantic (Squire, 2014, p. 1; Bernanke, 2010, p. 35-36).

The most common arguments in favour of State aid packages are the maintenance of systemic stability, restoring trust on the markets, risk reduction and the balancing of interests of investors, financial institutions and the society (Lastra, 2015, p. 4; Cordella and Yeyati, 2003, p. 300). The counterarguments are numerous: State aid measures can diminish competition, preferential treatment of larger banks is often noticeable - they are either too big to fail or systemically relevant. State aid packages can also be considered a form of freebie to shareholders. Additionally, State aid packages might remove incentives for private initiatives (Woll, 2014, p. 2). A moral hazard issue is worth stressing here as well - if big corporations know in advance that in case of a major financial failure they can expect to be bailed out by the State, this may increase their risk-taking attitude. On the other hand, economic analysis indicates that the risk-reducing "value effect" of ex-ante commitment to bailouts outweighs the moral hazard component of such policy (Cordella and Yeyati, 2003, p. 300).

As a consequence of the 2008 global financial crisis, States intervened in the economy on both sides of the Atlantic. The study of the efficiency and effects of State aid is an interdisciplinary area, seeing as granting State aid is based on policy decisions (Squire, 2014, p. 1) and their effects can be measured by economic analysis. The interdisciplinary nature of this matter reveals itself within the legal science too - competition law, State aid rules, central banking, monetary and fiscal regulation, corporate law and insolvency law are all relevant here. Finance or banking are among the sectors most affected by this matter. Although most bailouts took place in the car, airline and railroad industries, State interventions in the financial sector received more attention due to its special intermediary position than State aid measures received by other industry sectors.

In the most difficult years of the financial crisis - in 2008-2014 - 671 billion Euro was used in the EU in the form of capital and repayable loans; an additional 1288 billion Euro was provided in the form of guarantees ${ }^{2}$. Over 450 State aid decisions were issued by the EC, which approved the restructuring or orderly resolution of 112 European banking institutions. Around $25 \%$ of the entire European banking sector was ultimately restructured under EU State aid rules during that time. Out of the top 20 European banks, the Commission approved aid to 12: six were restructured, five received aid through approved aid schemes and one was liquidated (Adamczyk and Windisch, 2015, p. 1).

\footnotetext{
Regulations (EU) No. 1093/2010 and (EU) No. 648/2012, of the European Parliament and of the Council (OJ L 173, 12.06.2014, p. 190).

2 See Commission Competition Scoreboard, 2014, available at http://ec.europa.eu/ competition/state_aid/scoreboard/index_en.html (last accessed on 10.08.2016).
} 
According to the national expenditure reports for 2014, Member States spent 101.2 billion Euro (0.72\% of GDP) on State aid. Some Central and Eastern European (hereinafter, CEE) Member States granted significant amounts of State aid to their financial sectors. In 2014 for example - aside from Germany - Poland, the Czech Republic and Hungary spent the most on State aid measures related to their financial sectors ${ }^{3}$. However, apart from the aforementioned three of the 12 CEE Member States - the available data shows that most of the State aid cases were submitted by non-CEE members of the EU and specifically, by Eurozone members and by the UK ${ }^{4}$. Importantly also, GDP-based statistical data shows that the volume of State aid was more significant in the latter regions as well (Adler, Kavanagh and Ugryumov, 2010, p. 66).

As a consequence of the above State aid measures, significant improvements were made - operational and risk indicators of the affected financial institutions were improved, as were their funding and solvency positions. In the Eurozone, the European Central Bank (hereinafter, ECB) developed more frequent and stricter review mechanisms and stress tests, and the Single Supervisory Mechanism (SSM) was set up. On the other hand, the lack of a full banking union in the EU, the fact that the monetary union is limited to the members of the Eurozone only, in combination with the lack of a fiscal union (coordination of budgetary revenues (taxes) and expenses (social redistributive systems)), has led to far-reaching consequences.

Member States not party to the Eurozone have had more flexibility because they can conduct their own monetary policy, even if strictly coordinated and supervised by the ECB. Countries like Spain got into a difficult financial situation because they also undertook the obligations put forward in the Fiscal Compact. The fact that Spain does not have a separate monetary policy has limited its options as to the management of the financial crisis. In other words, the Bank of Spain could not function as a lender of last resort, and the ECB has not used the available monetary policy tools as much as it could have done ${ }^{5}$. It would be too early to make final conclusions as to the long-term effects of State aid measures in the EU.

3 Ibidem.

${ }^{4}$ Statistical data available at the State aid register of the EC, available at http://ec.europa. eu/competition/state_aid/register/ (last accessed on 10.08.2016). The followings are the most important, financial sector-related State aid cases approved by the EC. UK: C14/2008, N1/2014, NN41/2008, N194/2009, N1/2014, SA.38304, N422/2009, N621/2009, SA.29834, N428/2009, NN19/2009, SA.33683. Spain: N202/2010, N392/2010, NN61/2009, SA.33095, SA.33733, SA.33733, SA.33096, SA.33734, SA.33734, SA.38143, SA.33103, SA.33402, SA.34255, SA.33735, SA.33735, SA.39402, SA.33917, SA.33917, SA.34053, SA.34536, SA.36249, SA.34820, SA.35253, SA.35369, SA.35488, SA.35489, SA.35490, SA.36500. Hungary: C37/2010, SA.40441.

5 Treaty on Stability, Coordination and Governance in the Economic and Monetary Union. 
This is so especially because a sovereign debt crisis (the inability of a significant number of EU member states, mostly Eurozone member states, to fulfil the criteria set by the EU as to State budget and deficit) has developed as of 2011 that has further led to a political crisis in several EU countries, especially in Greece, the UK and Spain. These problems are connected to the State aid measures under review in this paper seeing as they have contributed to the unprecedented increase of the sovereign debt in most EU Member States. The outcome of the relevant State measures could have been different in Europe (more similar to US developments), if the banks had paid back the aid which they had received (with interest rates). It can be concluded therefore that the assistance given to failing banks proved even more controversial in Europe than in the US.

\section{EU State Aid Rules and their Interplay with EU Competition Law}

State aid rules are interlinked or rather based on the competition law of the European Union. In the internal market, a distortion of competition is not permitted since that would lead to the worsening of the situation of European consumers. Based on the Treaty on the Functioning of the European Union (hereinafter, TFEU) ${ }^{6}$, State aid is, as a general rule, incompatible with the internal market with two groups of exceptions. The first is provided directly in the TFEU which states that some types of aids are in fact compatible with the internal market. The second group of exemptions covers measures that may be considered compatible with the internal market. Here, the Commission is authorized to evaluate which State aid may be considered compatible. From the point of view of this article, the category "aid to promote the execution of an important project of common European interest or to remedy a serious disturbance in the economy of a Member State"7 has been most frequently referred to in State aid cases proliferated as a consequence of the 2008 financial crisis.

The law on this area should foster economic and policy goals. One of the most important questions as to State aid policy is therefore related to its effects on market structure, on competition and on consumer welfare. In the EU, State aid is permitted as long as it does not lead to a distortion of competition on the relevant market, and, if it is a priori approved by the Commission. The EC may attach conditions to the State aid in order to clear it. The authority may also provide adequate compensation for other market players affected by the measure.

\footnotetext{
6 TFEU, Articles 107-109.

7 See TFEU, Article 107(3)(b).
} 
In other words, European State aid rules aim to limit the distortions of competition created by the measure to the necessary minimum, and give strict conditions for granting permission to a State aid measure. They include the "one time - last time" principle, which ensures that State aid measures are used exceptionally, only in a situation of a systemic risk. The State requesting an approval from the EC has to prove that there will be a limited distortion of trade between Member States and that the compensatory measures imposed by the Commission - such as a duty to sell part of the assets of the beneficiary to a competitor or changing its management - will together ensure the limitation of the distortion.

The TFEU allows for State aid exceptionally and in order to remedy a serious disturbance in the economy of a Member State of the EU ${ }^{8}$. Any measures above a certain threshold, in other words, excluding de minimis measures ${ }^{9}$ - that are qualified as State aid, must be approved by the Commission before they can take place (Whish, 2010, p. 240-241) ${ }^{10}$.

The Commission makes a case by case assessment and issues its approval. First, it analyses whether the measure constitute "aid" at all. In this respect, it applies the "private market economy investor test" (hereinafter, PMEIT). If the State acts like a private investor, then the measure is not categorised as State assistance. On the other hand, if normal return on the investment cannot be expected within a reasonable timeframe, the PMEIT is not met. The following question in the Commission's analysis is whether the State aid measure is compatible with the provisions of the TFEU, that is, with EU competition law.

\section{Changing Interpretation of the State Aid Rules and its Impact}

The "temporary and extraordinary rules" introduced starting from $2008^{11}$ and the extension of the "no-State aid" category ${ }^{12}$ created an area where the Commission itself deflected from relevant EU laws (Ghazarian, 2016, p. 228).

8 Article 107(1) and Article 107(3)(b) TFEU.

${ }^{9}$ The de minimis regulation allows State aid without authorization when the total amount of aid does not exceed EUR 200000 during the period of three fiscal years (Art. 3 of Commission Regulation (EU) No. 1407/2013 of 18 December 2013 on the application of Articles 107 and 108 of the Treaty on the Functioning of the European Union to de minimis aid, OJ L 352, 24.12.2013, p. 1).

10 Private market economy investor test (PMEIT) - there is no State assistance if a private investor would act in the same way.

11 In Communications of the Commission (2009-2013) about the principles of granting state aid to financial institutions; available at http://ec.europa.eu/competition/publications/reports/ working_paper_en.pdf (last accessed on 10.08.2016).

12 In 2013 Banking Communication of the Commission (Communication of 10 July 2013 on the application, from 1 August 2013, of State aid rules to support measures in favour of banks in 
The idea behind European competition law and State aid rules is that the economic advantages of the common market, increasing efficiency and competition lead to growing consumer welfare in the long run (Korah, 2009, p. 3). Based on relevant European jurisprudence, EU competition law provisions apply to the banking sector as well ${ }^{13}$. But in times of crisis, more urgent aims must take precedence - such as systemic stability. The EU solved this conflict of priorities so as for EU competition rules to prevail and to be respected even in times of crisis ${ }^{14}$. At least this is the declared intention of the EU and the fundamental principle underlying the policy of DG Competition of the EU Commission.

However, an analysis of the enforcement practice of the EC post-2008 shows that the Commission has in fact applied a far more flexible approach in this area than in its previous cases. Indeed, almost all State aid applications submitted by Member States have been approved in this time period. The EC issued six relevant Communications in 2008-2013 about compatibility requirements and the importance of consistency ${ }^{15}$. Also in the bailout of Northern Rock in late 2007, the Commission decided that interest-bearing State-liquidity assistance with sufficient collateral in emergency is not in fact distortive (Lastra, 2015, p. 4.31) ${ }^{16}$.

the context of the financial crisis, OJ C 216, 30.07.2013, p. 1); available at http://eur-lex.europa. eu/legal-content/EN/ALL/?uri=CELEX:52013XC0730(01) (last accessed on 10.08.2016).

13 CFI judgment of 14 July 1981, Case 172/80 Gerhard Züchner v Bayerische Vereinsbank $A G$, ECLI:EU:C:1981:178.

14 In Communications of the Commission (2009-2013) about the principles of granting state aid to financial institutions, available at http://ec.europa.eu/competition/publications/reports/ working_paper_en.pdf (last accessed on 10.08.2016).

15 See Banking Communication; Communication from the Commission of 1 December 2011 on the application, from 1 January 2012, of State aid rules to support measures in favour of banks in the context of the financial crisis, OJ C 356, 06.12.2011, p. 7; Communication from the Commission of 1 December 2010 on the application, after 1 January 2011, of State aid rules to support measures in favour of banks in the context of the financial crisis, OJ C 329 , 07.12.2010, p. 7; Communication from the Commission of 23 July 2009 "The return to viability and the assessment of restructuring measures in the financial sector in the current crisis under the State aid rules", OJ C 195, 19.08.2009, p. 9; Communication from the Commission of 25 February 2009 on the Treatment of Impaired Assets in the Community Banking sector, OJ C 72, 26.03.2009, p. 1; Commission Communication of 5 December 2008 - Recapitalisation of financial institutions in the current financial crisis: limitation of the aid to the minimum necessary and safeguards against undue distortions of competition, OJ C 10, 15.01.2009, p. 2.

16 See also "Approval of the rescue package of UK Northern Rock (05.12.2007)", IP/07/1859 (05.12.2007); CFI judgment of 14 July 1981, Case 172/80 Gerhard Züchner v Bayerische Vereinsbank AG, ECLI:EU:C:1981:178; Commission Communication of 13 October 2008 The application of State aid rules to measures taken in relation to financial institutions in the context of the current global financial crisis, OJ C 270, 25.10.2008, p. 2, para. 51. 
Since late 2008, the Commission introduced "temporary and extraordinary" State aid rules specifically for the financial sector concerning the principles of granting State aid to financial institutions ${ }^{17}$. These rules include various Communications (2009-2013); they are quite unique in the legal sense. The EC has argued that its Communications have not shown a significant departure from State aid or competition law rules, but that they facilitate a faster decision-making process and more flexible procedures ${ }^{18}$.

The first rule stressed by the Commission in these Communications is the principle of non-discrimination. Second, an application for State aid can only be granted if the State aid measure is clearly defined, limited in time and scope, adequately paid for by the beneficiaries that should bring an appropriate contribution towards their own need, and subject to behavioural constraints so as to prevent any abuse of the State support, such as aggressive expansion riding on the back of the State guarantee. The remuneration for a capital injection made by a State into a bank should reflect the price that a normally functioning market would require for the relevant capital (Commission). Finally, the planned State aid measure should demonstrate strategies to remedy unsustainable business models and achieve long-term viability without the State support under adverse economic conditions (structural adjustment measures).

The second shift in the approach of the EC in this area is visible in its interpretation of the "no-State aid" category. The latter has been extended as a result of the 2008 financial crisis, in other words, the Commission gave the term a wider interpretation as compared to that found in its pre-crisis case law. A measure falls now into the category of "no-State aid" if: the aid is provided for a temporarily illiquid yet solvent entity, the aid is not part of a large rescue package, it is fully collateralized, if an interest rate is charged from the beneficiary, if it is initiated by the central bank and not backed by any counter-guarantee of the State ${ }^{19}$. Importantly, these are cumulative conditions. Also, the reimbursement of depositors by the deposit insurance fund is not considered to be State aid ${ }^{20}$.

17 State aid temporary rules established in response to the economic and financial crisis, available at http://ec.europa.eu/competition/state_aid/legislation/temporary.html (last accessed on 10.08.2016).

18 Commission Communication of 13 October 2008 - The application of State aid rules to measures taken in relation to financial institutions in the context of the current global financial crisis, OJ C 270, 25.10.2008, p. 2, para. 51.

19 See the Commission Communication of 2013.

20 Ibidem. 


\section{CEE Specific Implications of the Changing Interpretation of State Aid Rules}

The aforementioned tendencies were coupled with the pre-crisis differences in market structure and variations in regulatory framework. Together, they have led to different effects on market structures and consumer welfare in the Eurozone and non-Eurozone areas, mostly the Eastern segments of the European Union. As such, they are thus inconsistent with the European common market. The Commission tried to minimize the resulting distortion of competitions through the application of the principle of exceptionality and different compensation measures, but these efforts have proven at least partly unsuccessful.Case statistics show that there were 86 State aid cases after 2008 in the CEE region designed to remedy serious disturbances in the economy that related to the financial services industry. By contrast, there were as many as 385 similar cases in the rest of the EU (Lastra, 2015, p. 4.31). Importantly also, not only was the number of approved State aid packages far greater in Western EU countries than in their CEE neighbours, but so was the amount of money at stake and the amount of financial assistance given to their failing banks. It is relevant to note however that there were more guarantee and liquidity schemes provided for the financial system as a whole than individual bank bailout cases. In other words, EU Member States' governments preferred to request Commission approvals for overall aid schemes, rather than the assessment of bailouts of specific banking entities.

Massive State aid packages, the preferential treatment of the largest financial institutions through EU State aid mechanisms - none of which were $\mathrm{CEE}$ in origin ${ }^{21}$ - have led to the distortion of competition on the common market, mainly because of the prioritization of the stability of the financial sector and the common currency. In the long-run, this approach has led to unprecedented sovereign indebtedness and contributed to an increased economic and political instability of the EU, particularly in its most vulnerable CEE segment.

Most of the non-Eurozone Member States of the EU are in fact located in the CEE region ${ }^{22}$. There are some specific characteristics of the financial crisis in this part of Europe. Its deep dependence on foreign investments implied, for instance, that any major economic disturbance would have had

21 Central and Eastern European Countries (CEECs) is an OECD term for the group of countries comprising Albania, Bulgaria, Croatia, the Czech Republic, Hungary, Poland, Romania, the Slovak Republic, Slovenia, and the three Baltic States: Estonia, Latvia and Lithuania. See at https://stats.oecd.org/glossary/detail.asp?ID=303 (last accessed on 10.08.2016).

22 Bulgaria, Romania, Hungary, Czech Republic, Poland, Lithuania and Latvia. 
even more serious consequences for the economies of CEE countries. In the banking sector, the subsidiaries of foreign banks limited or stopped financing their own subsidiaries located in CEE when they, themselves faced liquidityrelated problems starting from late 2008. Another major source of problems and financial risk in the CEE region derived from the use of foreign exchange denominated loans. This was true especially in Hungary and Croatia but also in several other CEE countries.

The lack of confidence in the market has led to another problem starting from late 2008. Banks changed, or rather limited their lending activities. Governments tried to use several incentives to boost lending once again but with very limited success. As the financial crisis led to an economic crisis, the crisis caused by the lack of trust on the markets has only gotten deeper in the following years. This explains why most of the State aid measures approved by the Commission took the form of liquidity or guarantee schemes, rather than direct loans or tax releases. In general, financial institutions remained solvent, albeit struggling with liquidity issues. There has, however, been a perceivable lack of confidence among market players themselves and towards the financial sector as a whole.

\section{Conclusions}

It can be concluded that State aid measures need to be properly regulated and limited in order to avoid their distortive effects. Market players should also not be able to predict them in order to prevent the aforementioned moral hazard issues. The paper argues that State aid for failing banks may have had important positive short term effects in the EU, such as promoting the stability of the banking system and the common currency. In the long-run however, it has contributed to unprecedented sovereign indebtedness and to an increased economic and political instability of the EU, particularly in its most vulnerable CEE segment.

State aid measures are part of early intervention measures, along with the enforcement of prudential regulations. Their argued aim is to reduce loss and avoid financial contagion in the highly interlinked financial sector. If government rescue measures are predictable, it can create a "moral hazard" whereby banks may engage in more risky business activities safe in the knowledge that they will get bailed out by the public hand if things turn out badly. Therefore, more tailor-made regulatory solutions are needed (Hüpkes, 2000, p. 15-16).

State aid measures are subject to extensive debate in economic literature for a number of reasons too. Their economic effects depend on the size 
of the country at stake as well as a number of other factors. Some argue that the Commission should ban subsidies granted by small countries since these will most likely result in a price rise and productive efficiency increase (Głowicka, 2008, p. 62). Moreover, if countries grant subsidies strategically, they can improve the position of the subsidized home firm at the expense of a foreign company (Brander and Spencer) (Głowicka, 2005, p. 1). In truth, measuring the effects of State aid packages is complicated partially because of the inherently limited transparency of public finances (Acemoglu and Verdier, 2000 , p. 194). It is also complicated by the fact that a State can apply numerous types of direct and indirect financial, economic and legal methods and policies in this context.

The role of the government in correcting market failures is unquestionable. In reality however, many government failures or imperfections can be observed also (Baldwin and Robert-Nicoud, 2007, p. 21). Government interventions in the CEE region were extensive, including not only State aid schemes but also nationalization, sometimes of as much as $60 \%$ of the financial sector in certain jurisdictions (especially in Hungary). Based on the case statistics and data gained from the State aid register of the Commission, this article demonstrated that the flexibility of the Commission in the area of State aid assessment - combined with economic and policy-related circumstances - have contributed to a dilution of competition law and an increasing presence of uneven market conditions.

\section{Literature}

Acemoglu, D. and Verdier, T. (2000). The choice between market failures and corruption. American Economic Review, 90(1), 194-211.

Adamczyk, G. and Windisch, B. (2015). State aid to European banks: returning to viability. Competition: State aid brief. Occasional papers by the Competition Directorate - General of the European Commission, 1, 1-7. Retrieved from: http://ec.europa.eu/competition/ publications/csb/csb2015_001_en.pdf (10.08.2016).

Adler, E., Kavanagh, J. and Ugryumov, A. (2010). State Aid to Banks in the Financial Crisis: The Past and the Future. Journal of European Competition Law \& Practice, 1(1), 66-71, http://dx.doi.org/10.1093/jeclap/lpp006.

Baldwin, R.E. and Robert-Nicoud, F. (2007). Entry and Asymmetric Lobbying: Why Governments Pick Losers. CEP Discussion Paper No. 791. London: Centre for Economic Performance. Retrieved from: http://cep.lse.ac.uk/pubs/download/dp0791. pdf (10.08.2016).

Bernanke, B.S. (2015). The Courage to Act: A Memoir of a Crisis and Its Aftermath. New York: W.W. Norton \& Company. 
Cordella, T. and Yeyati, E.L (2003). Bank bailouts: moral hazard vs. value effect. Journal of Financial Intermediation, 12(4), 300-330.

Ghazarian, L. (2016). The Obligations of Member States, National Courts and National Authorities in State Aid Recovery and Recent Developments in the Case-Law of the Court of Justice of the European Union. European State Aid Law Quarterly, 15(2), 228-234.

Głowicka, E. (2005). Rescue and Restructure Subsidies in the European Union. Berlin: Social Science Research Center Berlin (WZB). Retrieved from: http://www.etsg.org/ ETSG2005/papers/glowicka.pdf (10.08.2016).

Głowicka, E. (2008). State Aid and Competition Policy: The Case of Bailouts in the European Union. Berlin: Humboldt-Universität zu Berlin. Retrieved from: http://edoc.hu-berlin. de/dissertationen/glowicka-elzbieta-2008-05-08/PDF/glowicka.pdf (10.08.2016).

Hüpkes, E.H.G. (2000). The Legal Aspects of Bank Insolvency: A Comparative Analysis of Western Europe, the United States and Canada (Studies in Comparative Corporate and Financial Law). The Hague: Kluwer Law International.

Korah, V. (2009). An Introductory Guide to EC Competition Law and Practice. Oxford: Hart Publishing.

Lastra, R.M. (2015). International Financial and Monetary Law. Oxford: Oxford University Press.

Lipinsky, J. and Wolters, J. (2016). Time will Tell - A Brief Contemplation on the Temporal Application of Substantive State Aid Rules in the Light of the Recent AndersenJudgment of the CJEU. European State Aid Law Quarterly, 15(2), 193-198.

Squire, R. (2014). Insolvency vs. Illiquidity in the 2008 Crisis and the Congressional Imagination. Fordham Law Legal Studies, Research Paper No. 2392914, February 8, 93-116. Retrieved from: http://ssrn.com/abstract=2392914 (10.08.2016).

Whish, R. (2010). Versenyjog [Competition Law]. Budapest: HVG-ORAC.

Woll, C. (2014). The Power of Inaction: Bank Bailouts in Comparison. Ithaca: Cornell University Press. 